\title{
"Will this picture help win the war"?: Band of Brothers and the Mythology of World War II
}

\section{Anne Mørk}

University of Southern Denmark

\begin{abstract}
This article examines the mythology that has evolved about World War II in American culture, and how the film and television industry has played a crucial part in this development. The miniseries Band of Brothers (2001) is analyzed by applying parts of this mythology, as well as the context of the revival of WWII in popular culture that occurred after the end of the Cold War: Band of Brothers rejected the myth that war was without consequences for those who experienced it, but it confirmed the myths that WWII was fought by a particularly heroic generation and that WWII was a "good" war compared to less successful campaigns, especially the Vietnam War. Thus, the miniseries is similar to other works in that era in using WWII to heal the nation's wounds after the humiliation and trauma of Vietnam. It is argued that Band of Brothers brought renewed force to these myths with its focus on authenticity and "truth."
\end{abstract}

Keywords: Film-World War II-Steven Spielberg-mythology-the Greatest Generation-warfare

Despite its end almost seven decades ago, World War II remains a subject of intense interest in both scholarly circles and in popular culture. WWII is remembered for victorious battles, such as The Battle of Iwo Jima and DDay; in comparison the Vietnam War is remembered for the embarrassment of the Tet Offensive and the horror of the My Lai massacre. WWII implies victory, heroism, and the triumph of democracy. Its surrounding mythology has contributed to the fundamental notion of American identity and how 
it relates to the rest of the world. WWII has become "the Good War" in the American mind, a just and necessary war. The acknowledgment of the existence of evil justified the use of violence and led to the notion of a just war. Furthermore, the veterans of the war are celebrated as "the Greatest Generation." The interest in the subject reached new heights in the 1990s, Veterans were encouraged to tell their stories in order not to let the truth about the war die with "the Greatest Generation." The public's conception of the war had been defined by myths that idealized the war and the American contribution to it. One of the responses to this request for truth and authenticity was the HBO miniseries Band of Brothers which depicted the real-life wartime experiences of Easy Company in Europe during WWII. It is the purpose of this paper to identify the mythology of WWII as expressed in Band of Brothers in relation to the revival of WWII in the 1990s. The paper also explores the role of films in the expression and implementation of WWII as a national myth.

1989-2001 was the time of a WWII revival. 1989 marks the beginning of the end of the Cold War (the fall of the Berlin Wall), as well as the 50th anniversary of the start of WWII. In these years, America looked inward due to the lack of an external enemy. This is not to suggest that the war has no been an issue in American culture before or after this decade, but simply that WWII was the subject of an unusually high degree of interest in these years that, in hindsight, represented a cultural vacuum between two nation. al traumas- the Vietnam War and September 11, 2001. The myths of WWI were used to cope with the trauma of Vietnam, in the process developing new tendencies in the WWII mythology and contributing to contemporary political debates. The revival of the war particularly focused on the mora justification for the war, as well as the hardship endured by the soldiers.

The film industry and visual media have been central to the creation of WWII mythology. The success of historical films and television series de pends on their appeal to contemporary audiences and especially their abil ity to indirectly reflect contemporary issues. The film industry was centra in the creation of the myths of WWII to the public; similarly, it became crucial factor in the revival of the war. ${ }^{1}$ The revival of the WWII genre it the 1990s has been regarded as a reaction to the Vietnam War films, many 0

I Chambers, John Whiteclay II, and David Culbert (eds.), World War II, Film, and History (New York: Ox ford University Press, 1996), p. 10. 
them anti-war films, of the 1970s and 1980s. ${ }^{2}$ The Vietnam War questioned the positive myths about the military and warfare. The need for a return to "the Good War" seemed more urgent than ever to heal the wounds of Vietnam. In the mid-1990s, Hollywood contributed to the national revival of WWII with a wave of WWII films - and war films in general. In 1998, two noticeable WWII films-Steven Spielberg's Saving Private Ryan and Terrence Malick's The Thin Red Line-marked the revival of the genre. A general theme in the war movies of those years was the focus on authenticity, a tendency which is particularly dominant in Band of Brothers.

\section{Choosing Band of Brothers}

Band of Brothers is a miniseries created for television, but in this paper it will be considered as part of a tendency that appeared primarily in the film industry. The series was created mainly by people known for their work in film, e.g. Steven Spielberg and Tom Hanks. The creators, the historical accuracy (in terms of weapons, costumes, etc.), the budget, and the scope of the production have more in common with the film industry than with television. The series' aesthetic expression is influenced by films; especially the combat scenes are heavily influenced by Saving Private Ryan. ${ }^{3}$ The highprofile nature of the production places Band of Brothers in the same category as Hollywood blockbusters rather than the average miniseries. Most importantly, Band of Brothers is considered one of the most realistic WWII films due to its use of "historical pieces," and it is thus a prime example of Hollywood's renewed interest in authenticity.

\section{Myth and Method}

The analysis of Band of Brothers will rely on three widespread myths about WWII. Popular cultural narratives are not merely false stories, and it is not the purpose of this paper to validate or debunk, but to analyze the underlying mythos in Band of Brothers to discern the public consensus about the ideals, values, and memories of World War II. First, it is important to clarify and define the concept of political mythology. 
Christopher G. Flood defines political myth as "an ideologically marked narrative which purports to give a true account of a set of past, present, of predicted political events and which is accepted as valid in its essentials by a social group." ${ }^{4}$ Political myths are particularly important to modern soci. eties because they, rather than religion, ethnicity, or tribal relations, define the national community and the shared experience within the state. Thus, political myth is separate from the sacred. ${ }^{5}$ According to Benedict Ander son's classic Imagined Communities, national myths do not replace reli. gion, but they do provide a similar sense of community that is not explici or programmatic, like political ideologies. ${ }^{6}$ Political mythology is central to the establishment of a collective memory, ideals, and values. Myth can be regarded as the expression and manifestation of national and cultural identity, but it also provides the justification for future events/actions. As argued by Flood, myth is only possible within an atmosphere of consensus-thus the message and the reception must be mutually supportive. ${ }^{7}$ Political myth play a significant part in the creation of national identity as they help "indi viduals and communities mediate their personal and collective anxieties? Through political myths, "they are able to understand, express and commu nicate to themselves and others a sense of their identity as members of spe cific social, cultural, and national groups." ${ }^{\prime 8}$ According to Richard Slotkin political myths can be communicated through the educational system, th media, or popular culture. They provide a shared point of reference and language of nationality, a common form of speech and reading, a commo ideology or moral vocabulary, a common set of historical fables, a pantheo of culture heroes." Other expressions of national myths can be rites suc as presidential inaugurations, commemorative dates such as the Fourth July, or memorials such as that to the veterans of the Vietnam War. ${ }^{10}$

4 Flood, Christopher G., Political Myth: A Theoretical Introduction (New York and London: Routledg 2002), p. 44.

5 Flood pp. 41-42.

6 Anderson, Benedict, Imagined Communities: Reflections on the Origin and Spread of Nationalism (Lo don: Verso, 2006), pp. 11-12.

7 Flood, p. 43.

8 Foster, Kevin, Fighting Fictions: War; Narrative and National Identity (Sterling, Virginia: Pluto Pre 1999), p. 2.

9 Slotkin, Richard, "Unit Pride: Ethnic Platoons and the Myths of American Nationality" in American I erary History, Vol. 13, No. 3 (Fall 2001), p. 471, [Online]. http://muse.jhu.edu.proxy1-bib.sdu.dk:20journals/american_literary_history/v013/13.3slotkin.pdf

10 Flood p. 42. 
Political myth incorporates both the inclusion of the past and the future, establishing a sense of purpose and a justification for current political or social decisions. By creating a romanticized version of the past, myth is an instrument to implement contemporary agendas. Roland Barthes has written at great length about the cultural manifestations of mythology. He describes myth as the process that purifies past events: "it makes them innocent, it gives them a natural and eternal justification," and it removes any sort of human complexity or doubt from their meaning. ${ }^{11}$ This proves particularly useful in the justification and implementation of contemporary agendas. Henry Tudor argues that "a myth is always told from the standpoint of the present,"12 which means that myths are always changing to explain contemporary conditions and purposes. Thus, the study of myths must necessarily include the study of the particular "present" in which they arose.

Despite the persistence of national symbols and the widespread acknowledgment that imagined communities do indeed exist, the discussion of myth in the field of American Studies has been characterized by academic disagreements about the purpose and usefulness of such studies. The mythand-symbol school that developed within American Studies between c. 1950 and 1965 focused on the identification of recurring myths and symbols in American culture, as a way to define a specific American national identity. This approach was identified with scholars such as Leo Marx, Henry Nash Smith, and Alan Trachtenberg. ${ }^{13}$ However, it was attacked for its lack of a unified methodology, and it was considered a legacy of a consensus approach to history. ${ }^{14}$ Critics of the 1970 s and 1980s argued that the belief in the existence of myths reflected an elitist approach to American national culture that was simplistic and devoid of consideration for minority struggles.

Yet, in recent years the aforementioned work by Flood and many others have shown that studying political mythology can still be a legitimate way

11 Barthes, Roland, Mythologies (London: Paladin, 1973), pp. 155-156.

12 Tudor, Henry, Political Myth (London: Macmillan, 1972), p. 125.

13 See Leo Marx, The Machine in the Garden: Techonolgy and the Pastoral Ideal in America (New York: Oxford University Press, 1964); Henry Nash Smith, Virgin Land: The American West as Symbol and Myth (New York: Vintage Books, 1950); Alan Trachtenberg, Brooklyn Bridge: Fact and Symbol (Chicago and London: Chicago University Press, 1965).

14 Umberger, Daryl, "Myth and Symbol" in Encyclopedia in American Studies, ed. Miles Orvell. Baltimore: Johns Hopkins University Press, 2010, pp. 1-3 [Online]. http://eas-ref.press.jhu.edu.proxy1-bib.sdu. $\mathrm{dk}: 2048 /$ view? $\mathrm{aid}=56 \&$ from=search\&query $=$ myth $\% 20$ and $\% 20$ symbol\&link=search $\% 3$ Freturn $\% 3 \mathrm{D} 1 \% 2$ 6query\%3Dmyth\%2520and\%2520symbol\%26section\% 3Ddocument\%26doctype\%3Dall 
of identifying characteristics in American culture. Furthermore, in the study of media it can be a helpful tool in analyzing the success of a particular genre/series with the American audience. Myth can be seen either as the vehicle of political and cultural justification, as in Flood and Slotkin, or as a pejorative term that implies the lack of truthfulness. ${ }^{15}$

In American historical memory, WWII is fundamentally different from other wars. Indeed, it has become the creation myth of the modern American superpower. Also, focus on war and the military reveals important aspects of national mythology as they focus on the defence of the state and thereby one of the basic foundations of the nation's survival. ${ }^{16}$ The most important public memory of WWII was of the war as a positive experience for the American people. The death of thousands of U.S. soldiers has consistently been presented as the necessary sacrifice to give birth to the American century. ${ }^{17}$ While Europe was left in ruins, America emerged as the world's greatest power; WWII made America's emergence as superpower possible - economically, politically, and militarily. It justified extensive political and economic intervention in Europe. The close ties to the "liberated" peoples (the Europeans, the Japanese) after the war have only strengthened the Americans' sense of justification for the war.

Edward W. Wood Jr. identifies three central myths about WWII that will form the basis of the analysis of Band of Brothers: the myths of "The Good War," "The Greatest Generation," and the concept of just war. His objective is to debunk those myths and provide counterarguments. The most powerful myth about WWII is the notion of "the Good War." It was a defensive war, and fascism was responsible for the killings of millions of innocent civilians. Thus, America's motivation for intervention cannot be questioned. WWII was perceived as a struggle for freedom and democracy, a fight against "evil." It is believed that due to the selfless nature of the American involvement, U.S. soldiers were not traumatized by the fighting. ${ }^{18}$ The public is under the impression that Americans did not participate in brutal, random killings (there were no reports of a My Lai in Europe). However, in

15 Flood p. 44.

16 Slotkin pp. 471-472.

17 Terkel, Studs, The Good War: An Oral History of the World War II (New York: Ballantine Books, 1984), p. 8.

18 Wood, Edward W. Jr., Worshipping the Myths of WWII: Reflections on America's Dedication to War (Washington, D.C.: Potomac Books, 2006), pp. 39-54. 
interviews conducted by Studs Terkel several veterans admit disrespectful, brutal behavior towards European civilians. ${ }^{19}$ In the mythology, such actions have paled in comparison to actions of selfless heroism. Historically, there has been more focus on the American involvement in Europe than on the war against Japan in the Pacific. War crimes were committed by both sides in the Pacific, and one reason for the heightened focus on Europe might be an attempt to avoid dealing with the crimes committed by Americans in the Pacific.

Richard Polenberg lists a number of misconceptions about the war that have been part of the WWII mythology. First, the war is believed to have united the American people. Winning the war required a collective effort; true unity demanded disregard of racial and religious differences. The war is presented as a previously unseen opportunity for African Americans. They were able to participate in the fight against racism; e.g. they had better access to jobs. Women also had the chance to join the workforce and thereby support the war effort. WWII is widely considered a people's war, that it had a socially unifying effect. ${ }^{20}$ In contrast, during the Vietnam War many college students avoided the draft, leaving the lower social classes, and particularly African Americans, to do the fighting. The WWII military served as a melting pot for Americans from different social strata. To provide an example, no future U.S. president served in the Vietnam War. In comparison, Presidents Dwight D. Eisenhower, John F. Kennedy, Lyndon B. Johnson, Richard Nixon, Gerald Ford, Ronald Reagan, and George H. W. Bush all served in some capacity in WWII.

After the end of the war, the GI Bill offered opportunity for social mobility. Furthermore, World War I had left a negative impression of the domestic consequences of world war, e.g. the suppression of civil liberties and mob violence. The general notion is that none of this took place during WWII. America was able to maintain its democratic integrity despite the war. ${ }^{21}$ Polenberg's argument is that many of these ideas were in fact misconceptions. Among the examples are the racial segregation of the military,

19 An example is the interview with Red Prendergast, in Terkel pp. 46-55.

20 Polenberg, Richard, "The Good War? A Reappraisal of How World War Il Affected American Society," The Virginia Magazine of History and Biography, vol. 100, No. 3, The Home Front and Beyond: Virginians in the World War 2 Era (Jul., 1992), p. 296, [Online]. http://www.jstor.org.proxyl-bib.sdu.dk:2048/stable/ pdfplus/4249290.pdf?acceptTC $=$ true

21 Polenberg p. 296. 
the internment camps for Japanese-Americans, women being pushed out of the workforce after the war, and the government using threats and manipulation to control the media. ${ }^{22}$ In a 2006 article, James J. Kimble and Lester C. Olson presented evidence that the famous poster of Rosie the Riveter, which has become a symbol of the national effort, as well as of the genderunifying aspect of the war, was in fact virtually unknown during the war. This poster has become a powerful icon of the WWII mythology; yet, this status has been created fully in the post-war setting to suit fake conceptions about the war. ${ }^{23}$

The second myth is that the war was fought by "the Greatest Generation." Its focus is the individual, how average Americans brought fascism to its knees. U.S. soldiers were all heroes and sacrificed themselves for their country and fellow soldiers. ${ }^{24}$ Thus, WWII represents an extraordinary opportunity: it has the ability to focus on both large-scale, historical versions of the war and on individual experiences. The myth includes not just the nation as a whole, but also the sacrifices of the individual. Upon returning to the U.S., veterans attended college on the GI Bill and consolidated America as a land of material and democratic abundance. Ironically, the strongest criticism of the myths of "the Good War" and "the Greatest Generation" has come from veterans who felt that the mythology failed to adequately represent the reality of the war. ${ }^{25}$ America's view of its own greatness is further strengthened by the idea that America alone was responsible for the defeat of the Germans and the Japanese. In general, Americans have been ignorant of the sacrifices of its European allies, especially the Russians, and the Chinese. ${ }^{26}$

The third myth has defined America's view on war in general. This myth justifies the use of war when the enemy is "evil." The Holocaust provided unprecedented justification for the use of war, and the outcome of the war manifested violence as the appropriate answer to evil. ${ }^{27}$ Concerning the

22 Polenberg pp. 300-301, 314-321.

23 Kimble, James J. and Lester C. Olson, "Visual Rhetoric Representing Rosie the Riveter: Myth and Misconception in J. Howard Miller's "We Can Do it!" Poster in Rhetoric and Public Affairs, Vol. 9, No. 4 (Winter 2006), (include link), p. 537, [Online]. http://muse.jhu.edu.proxy1-bib.sdu.dk:2048/journals/rhetoric_and_public_affairs/v009/9.4kimble.pdf

24 Wood p. 76.

25 Fussell, Paul, Wartime: Understanding and Behavior in the Second World War (New York: Oxford University Press, 1989), p. 268.

26 Wood pp. 131-132.

27 Wood, p. 145. 
Holocaust, it has been very important for Americans to state that they did not know about the killings; any kind of American complicity in such acts would endanger America's reputation. Whereas the first two myths present the possibility to view America's participation in a positive and universal light, it is this third myth that is most relevant to the contemporary reader. It is this myth that is employed in current politics and culture as a justification for war and military engagements around the world.

\section{WWII and Film}

One of the main vehicles for the development and implementation of WWII as national mythology has been representations in film and television, and thus the myths of WWII have always been dependent on Hollywood. The war film as a genre has played a significant part in the public perception of war. According to Rikke Schubart, "the repeated viewing of genre films is a modern ritual where films function as myths anchoring the individual of a society to its collective myths." Furthermore, the war films not only comment on their subject, but also include references to current issues and provide a context for their audience. ${ }^{28}$ The films and documentaries screened on the home front during the war helped provide the foundation for the myths of war that developed after its end. ${ }^{29}$ Compared to the Vietnam War, which the American public could follow on their television screens, ${ }^{30}$ the public representation of WWII was provided by films and newsreels. They provided a romantic image of the war abroad-with the approval of the U.S. government. Since most Americans did not experience the war firsthand, public opinion has been particularly susceptible to the influence of Hollywood. ${ }^{31}$ In an act of part patriotism, part fear of government reprisals, Hollywood supported the war effort by producing films that romanticized the American intervention and its allies. ${ }^{32}$ The war was portrayed in films that directly concerned the war effort, such as Bataan (1943) and The Story of GI Joe (1945), as well as films indirectly referencing the war such as Tar-

28 Schubart, Rikke, "Storytelling for a Nation: Spielberg, Memory and the Narration of War," in Politicotainment: Televion's Take on the Real. Ed. Kristina Riegert (New York: Peter Lang, 2007), pp. 270-1.

29 Chambers and Culbert p. 4.

30 Basinger, Jeanine, The World War II Combat Film: Anatomy of a Genre (Middletown, Connecticut: Wesleyan Universituy Press, 2003), p. 191.

31 Chambers p. 3.

32 Polenberg pp. 299-303. 
zan Triumphs (1943). ${ }^{33}$ Significant aspects of the current mythology of the war were established at this point, e.g. the portrayal of the U.S. military as a melting pot, a people's army. ${ }^{34}$ According to Richard Slotkin, the platoon as symbol of multiculturalism has become a particularly American myth. Thus, the notion of an American character found an expression in the multiethnic platoons of the war movie, first seen in Bataan. Furthermore, officers were often portrayed as less democratic due to their elevated status. ${ }^{35}$

Already during the war itself, the World War II combat film emerged as a distinctive genre. ${ }^{36}$ Jeanine Basinger has identified five phases in the tradition of the WWII combat film. The first two took place during the war, followed by an absence of WWII films from the end of the war to $1949 .{ }^{37}$ The third phase, from 1949 to 1959 , marked the rise of films as an instrument of presenting WWII as a symbol of national pride and justification. This phase played a significant part in the process of the American nation coming to terms with the war, and several films in this phase achieved great popularity, among others Sands of Iwo Jima (1949) and Battleground (1949). ${ }^{38}$ From the early 1960 s to the early 1970 s, the fourth phase focused on epic recreations and provided historical information about battles in films such as The Longest Day (1962) and Battle of the Bulge (1965). In this phase, the war movie finally became the instrument of defining the national myth of WWII as films defined rather than portrayed historical reality. ${ }^{39}$ The fifth wave will be dealt with later in this paper. In the decades following the end of the war, the WWII genre remained highly popular with audiences and critics. Since the late 1940s, WWII has become the standard all other wars are measured against in both politics and the film industry, consolidating its position as a significant part of 20 th century American mythology. ${ }^{40}$

33 Zander, Ulf, Clio på bio: Om amerikansk film, historia och identitet (Budapest: Historiska Media, 2006), p. 119.

34 Polenberg pp. 301-302.

35 Slotkin pp. 469-470.

36 Basinger pp. 111-112.

37 Basinger pp. 110-111, 138.

38 Basinger pp. 140-142.

39 Basinger pp. 170-171.

40 Schatz p. 75. 


\section{Vietnam and "the end of victory culture"}

While WWII has remained a popular myth in American culture, the myths of war and the military as symbols of national pride suffered a setback in the 1970s and 1980s. The myths of "the Good War" and "the Greatest Generation" seemed inappropriate in the context of the Vietnam War. This diffused the distinction between enemies and allies, good and evil. Veterans were no longer part of "the Greatest Generation," but were often traumatized young men and women of low social status. The GI Bill had not just provided education, but also an opportunity for social mobility. For the veterans of Vietnam, the effect was often the opposite. ${ }^{41}$ This time, America did not emerge as a stronger nation. Instead, the Vietnam War led to a national identity crisis, in which mistrust of the government and the military was central. Many Americans felt that the nation had lost its sense of common purpose. ${ }^{42}$ During the Vietnam War, films on the topic were almost entirely absent, although one exception was the popular John Wayne film The Green Berets which transferred the heroism of WWII mythology to Vietnam. ${ }^{43}$ The Vietnam War caused what Tom Engelhardt has described as "the end of victory culture" in which the myth of war as a symbol of national pride suffered a serious setback. ${ }^{44}$ WWII movies of the 1960 s and 1970s, such as Kelly's Heroes (1970) and The Dirty Dozen (1967), reflected this new tendency which promoted antiwar sentiments and U.S. soldiers were portrayed as morally corrupt. This is Basinger's fifth wave of WWII movies. ${ }^{45}$ War films about Vietnam that appeared from the mid-1970s onwards were focusing mostly on the national trauma and the hardship of veterans. Many films portrayed the cruelty and pointlessness of war, as well as its dehumanizing effects. The political and historical context often present in WWII movies were absent from Vietnam films which instead focused on the life of soldiers. ${ }^{46}$ Most importantly, the American soldier was often

41 Turner, Fred, Echoes of Combat: The Vietnam War in American Memory (Anchor Books (Doubleday), 1977), p. 107.

42 Turner p. 34.

43 Basinger p. 192.

44 Engelhardt, Tom, The End of Victory Culture: Cold war America and the Disillusioning of a Generation (New York: Basic Books, 1995).

45 Basinger pp. 181-184.

46 Stahl, Roger, "Why We 'Support the Troops": Rhetorical Evolutions" in Rhetoric and Public Affairs, Vol. 12, No. 4 (Winter 2009), p. 537, [Online]. http://muse.jhu.edu.proxy 1-bib.sdu.dk:2048/journals/rhetoric_ and_public_affairs/v012/12.4.stahl.pdf 
portrayed as conflicted and, unlike the heroes of WWII, capable of actions of unspeakable evil against both other soldiers and Vietnamese civilians. ${ }^{47}$ The first wave of Vietnam films in the late 1970s, such as The Deer Hunter (1978) and Apocalypse Now (1979) were quagmire films, whereas the second wave of the late 1980s, such as Platoon (1986), Full Metal Jacket (1987), and Casualties of War (1989), focused primarily on the horrifying experiences of disillusioned grunts. ${ }^{48}$ Reflecting the growing cynicism and dissatisfaction in American society, the platoon no longer symbolized the myth of the unit as the embodiment of American values. ${ }^{49}$ However, in the 1980s a synthesis of the national pride of WWII and the national trauma of the Vietnam War appeared in films. Stahl argues that the new war films were both anti-war, focusing on the hardship and brutality of battle, as well as pro soldiers by focusing on the personal sacrifices of the soldier. ${ }^{50}$ This tendency would have a crucial impact on the WWII movies of the 1990s.

\section{The revival of WWII}

The revival of WWII was initiated by the 50th anniversary of the war in 1989. ${ }^{51}$ Public debate and especially renewed interest from Hollywood promoted the return of the WWII mythology. As argued by Stephen E. Ambrose, the members of "the Greatest Generation" were getting older and wanted to tell their stories to the public before it was too late. ${ }^{52} \mathrm{An}$ important concept central in the revival was authenticity-to find the "truth" about the war by telling the veterans' stories. It was important to let the younger generations (who had grown up in a world without large-scale war) know what their parents and grandparents had sacrificed for a safe world.

Two reasons are suggested for the renewed interest in WWII. America had been recovering from the Vietnam War for c. 15 years, and the country seemed prepared to confront its trauma. WWII is one of the most powerful myths in American culture in terms of unifying the nation, and thus the 50th

47 Suid, Lawrence H, Guts and Glory: The Making of the American Military Image in Film. Rev. ed (Lexington: The University Press of Kentucky, 2002), p. 10.

48 Engelhardt pp. 276-278.

49 Slotkin p. 490.

50 Stahl p. 538.

51 Paris, Michael (ed.), Repicturing the Second World War: Representations in Film and Television (Palgrave Macmillan, 2007), p. 9.

52 Schatz p. 75. 
anniversary represented a much needed opportunity for celebrating national glory. Another possible reason is that by the late 1980s the downfall of the Soviet Empire was becoming increasingly inevitable. For nearly half a century, American society had defined itself as the ideological counterpart to communism. Suddenly, American hegemony seemed natural and inevitable, but the country still needed a cultural focus. Modern America now had the time to reflect on its origins.WWII can, as previously mentioned, be viewed as a creation myth for modern American society. In the 1990s, the Cold War was replaced by smaller, regional wars, often civil wars based on ethnic strife. After decades of an ideological struggle with communism, ethnic conflicts in a far corner of Europe or genocide in Africa hardly fulfilled America's need for moral war. The increased focus on WWII in Hollywood was one way of satisfying America's need for a war between good and evil. The curious notion about the revival of WWII is that it happened during times of peace (or at least, in the absence of large-scale war) and American hegemony. Previously war films have experienced revivals in times of crisis and military conflict. ${ }^{53}$

Historical books provided part of the inspiration for the revival. Writers such as Stephen E. Ambrose and Tom Brokaw focused on the heroic actions of average Joes in the fight against fascism in Europe and the Pacific, and their narratives have become accepted components of WWII mythology. ${ }^{54}$ However, in the mid-1980s other views on the war began to appear. Studs Terkel's The Good War included oral stories of both the positive and negative aspects of the war. Howard Zinn, Edward J. Wood, Jr., and especially Paul Fussell contributed with more critical works. These works were critical not just of war itself, but of America's romantic obsession with WWII. Notable about the critics of WWII is that many of them are veterans; whereas "romantics" such as Ambrose and Brokaw never served themselves.

The revival of WWII occurred not only in the movie industry. An example of the mythology promoted by the revival was the creation of the World War II Memorial at the National Mall in Washington, D.C. The authorization to build the memorial was granted during the WWII revival (1993). ${ }^{55}$ The WWII Memorial is placed on the Mall's central axis near the Lincoln

53 Schatz p. 75.

54 Wood pp. 76-79.

55 "Facts - National World War II Memorial", [Online]. <http://www.wwiimemorial.com/default. asp?page $=$ facts.asp\&subpage $=$ intro $>$ 
Memorial and the Washington Monument - the only war memorial to do so. By the memorial's very location it contributes to the understanding of WWII as a myth of pride. Other war memorials, especially the Vietnam War Memorial, are subdued and focus on the tragedy of war and the loss of lives. In comparison, the WWII Memorial is magnificent and glorifying, reminding visitors of the people's "triumph." With the revival of WWII, war again became a symbol of pride and willingness to make personal sacrifices for one's country.

Yet, the mythology of WWII had been influenced by the trauma of the Vietnam War. This led to a curious paradox in the revival. On the one hand, the actions of American soldiers were idealized, and the enemy represented ultimate evil. On the other hand, there was an increased focus on the sacrifices U.S. soldiers had to make; the public had to be reminded that freedom had its price. The resulting myth seems to be that war is evil, but WWII was the exception. Soldiers witnessed and experienced horrible violence, but remained sane and compassionate. The tension between America's need for a myth of war and the acknowledgment of the brutality of war becomes increasingly obvious in the revival of the WWII film.

\section{The WWII movie}

Due to the close relationship between WWII and cinema, it is no surprise that Hollywood also wanted to remind the American public of the actions of "the Greatest Generation." The WWII genre was perhaps the most significant factor in the revival. The contemporary WWII genre represented "a collective return to history," 56 and thereby the opportunity for the American public to heal the wounds of Vietnam through films. The revival of the WWII genre-which also encouraged renewed interest in other war movies - served two purposes: to heal the wounds after Vietnam and to remind the American people of the glory and triumph of WWII. Thus, the myths of WWII proved to be the savior of a culture that had lost (some believed) its confidence and sense of history. According to Robert Burgoyne, the return of the genre was Hollywood's way of "offering audiences a 'way home' to a mythic America, reaffirming national identity after the crisis of Vietnam." ${ }^{57}$ The purpose of WWII films becomes to reinstate pride in the American values. 
In 1998, the release of Saving Private Ryan and The Thin Red Line marked the culmination of the revival of the WWII genre. Other WWII films that appeared during the revival include Paradise Road (1997) U57I (2000), Pearl Harbor (2001), Captain Corelli's Mandolin (2001), and Enemy at the Gates (2001). Not all of these focus on American aspects of the war, but rather illustrate the movie business' renewed interest in all things WWII.

Three main tendencies appear in WWII films of the 1990s: 1) focus on authenticity, 2) focus on brutality and the hardship of war, and 3) the increased focus on the Holocaust. Authenticity in the WWII genre can be accomplished by adaptations of real life stories, such as Band of Brothers. The authenticity of WWII movies is particularly important to the public acceptance of WWII mythology. By focusing on authenticity, WWII movies achieve a much higher degree of historical legitimacy, and thereby they enable their role as instruments of national myth and historical memory rather than simply providing entertainment. Rikke Schubart claims that after 1990 there was a rise in the use of so-called "historical pieces" in Hollywood war films. These can be clips, texts, etc., from the non-fictional world that are used in film and thereby provide the film with a connection to reality. ${ }^{58}$ Historical pieces are used to create a special connection between nation and history. ${ }^{59}$ She points out that the "historical piece" rarely appears in Vietnam films. ${ }^{60}$

Realistic depictions of battle and bloodshed also became increasingly important. Historically, WWII films have been surprisingly non-violent, thereby enforcing the romantic view of the war. In the revival, it was important to remind the American public of the sacrifices of U.S. soldiers. Because America prospered from the war, and because many did not experience battle firsthand, there has been much focus on showing that victory had a price. The most notable example of this tendency is Spielberg's Saving Private Ryan, both praised and criticized for its bloody depictions of battle. Extreme violence served to show the sacrifices of the U.S. soldiers. ${ }^{61}$ The focus on the brutality of war is related to the myth of "the Greatest Generation"- - only through the portrayal of the reality of war will the audience acknowledge the sacrifice of the veterans. 
The third tendency - focus on the Holocaust - is related to the myth of the just war. With Steven Spielberg's Schindler's List (1993), Hollywood rediscovered yet another angle of WWII-the Holocaust. Film and television were crucial to the American public's understanding and awareness of the Holocaust. According to Peter Novick, the Holocaust was absent from American public discourse between the end of WWII and the late 1970s. ${ }^{62}$ It was the overwhelming success (over 100 million viewers) of the 1978 four-part miniseries Holocaust that introduced this aspect of the war to the American people. Hollywood was more reluctant to debate the subject, Sophie's Choice (1982) being the only major Hollywood film before the 1990s on the Holocaust. However, the success of Schindler's List both created the foundation for renewed focus on the topic in Hollywood (the success of films such as The Pianist (2002) and Life is Beautiful (1997)), and served a political purpose. The Holocaust provided the opportunity to focus on the evil of the enemy, the universal appeal of war and served as an instrument for proving WWII the just war. ${ }^{63}$ Schindler's List premiered in the same year as the National Holocaust Museum in Washington D.C. opened, and material about the film was promoted through schools.

These three tendencies of the WWII revival, all appeared in Band of Brothers to which we now turn.

\section{Band of Brothers}

The miniseries Band of Brothers (2001) depicts the story of Easy Company of the 101 Airborne Division from its training in Georgia, to its landing behind enemy lines in Normandy on D-day through Holland, Belgium, and France, to the conquest of Eagle's Nest, Hitler's home in Bavaria. Easy Company participates in some of the best known battles of the war, such as D-Day, Operation Market Garden, and the Battle of the Bulge. During the course of the series, different members of Easy Company serve as protagonists, the company's leader Major Richard Winters being the central character that holds the story together. Each episode begins with the reallife veterans of Easy Company reminiscing about the war. However, we are not told the identity of each survivor until the last episode. Every episode,

62 Novick, Peter, The Holocaust in American Life (Boston and New York: Houghton Mifflin Company, 1999), p. 103.

63 Burgoyne., pp. 69-70. 
except the last, ends with a text of historical details that provides the viewer with a larger historical context, e.g. the number of men killed at a specific battle or how a maneuver performed by Easy Company on D-Day is still taught at West Point.

Band of Brothers premiered on cable network $H B O$ on September 9, 2001 , only 2 days before the terrorist attacks of $9 / 11$. The initial ratings were excellent, but dropped in the following weeks. HBO stopped their commercial campaign for the series as a response to public grief. It is possible that a series about large-scale war in the 1940s might seem rather dated in the era of terrorism. ${ }^{64}$

\section{The importance of authenticity}

Band of Brothers marks the culmination of the tendency of the WWII revival to focus on authenticity. The series was in part a response to the criticism of Saving Private Ryan for not being realistic enough. ${ }^{65}$ The series not only adapts a true story to the screen, but achieves additional credibility in its use of interviews. The survivors were involved in the production itself, thereby verifying the authenticity of the series. Finally, Band of Brothers stands out in its use of interviews with survivors of the war, thus providing both an emotional connection for the viewer and a legitimate sense of authenticity. Thereby, the series attempts to protect itself from accusations of using wrongful myths. Due to the use of interviews, Band of Brothers is a prime example of the use of "historical pieces" that has marked the post-Cold War production of war films. The kind of documentation used in the series is what Rikke Schubart referred to as a specific type of historical piece "memory" in which an eyewitness provides the present with a connection to the past. ${ }^{66}$ The historical pieces and the eyewitness accounts from the survivors of Easy Company shape the entire narrative. ${ }^{67}$ Compared to Saving Private Ryan, the depictions of battle are less bloody and violent. Violence in Spielberg's film is used to present the "reality" of war to viewers. In the series, such detailed depictions are not necessary since the historical credibility of the series is already secured by the use of interviews. Historical

64 Schatz p. 76.

65 Schubart p. 273.

66 Schubart p. 272.

67 Schubart p. 275. 
pieces both start and end each episode (the interviews, the historical text) and thus secure the sense of authenticity and realism for which other WWII films strive.

\section{The Good War?}

In the very first scenes of the series, the veterans of Easy Company reminisce how and why they joined the military. One veteran says: "Our country was attacked. It's a difference. It wasn't like Korea or Vietnam. We were attacked." 68 Thus, in the very first scene, WWII is portrayed as a just and necessary war; more importantly, it is emphasized as being fundamentally different from other American wars. Another veteran says that in his town three men committed suicide after being rejected for military service. Finally, a third veteran says: "I didn't do it for medals and I didn't do it for accolades, I did them because ... it's just what had to be done because it had to be done." In these three statements, the viewer has already been presented with three central components of the mythology: that it was a just war (the concept of "the Good War"), that it united people and gave a sense of common purpose (the melting pot), and that people were ready to fight for their country because it was the right thing to do ("the Greatest Generation"). Using eyewitness accounts from veterans validate these myths far more than any work of fiction ever could.

When the myth of WWII as the just war has been established, the series has greater freedom to challenge other myths. Much of the series is dedicated to showing the American public which sacrifices were made in the name of freedom. According to Edward W. Wood Jr., one of the major flaws of the WWII mythology is the ignorance about the trauma of the soldier. Not just witnessing killings, but committing themselves left many U.S. soldiers traumatized. ${ }^{69}$ The trauma of killing is only dealt with in one episode- "Crossroads"-in which Major Winters repeatedly remembers the experience of killing a German soldier. That the soldier was just a teenager and apparently defenseless worsens Winters' sense of guilt. However, this issue is not dealt with otherwise; the act of killing is often portrayed as necessary. In the episode "Carentan," the audience witnesses the nervous breakdown of Private Albert Blythe, but he is not part of the central group

68 "Currahee" (episode 1), directed by Phil Alden Robinson, Band of Brothers, HBO, 2001.

69 Wood pp. 39-54. 
of characters. Other soldiers also suffer mental breakdowns, but Blythe's makes him unable to protect his fellow soldiers, thus portraying him as the exception rather than the rule. ${ }^{70}$ Another issue that is explored in more depth is the issue of witnessing war and the killing of one's friends. In one of the interviews, a veteran fights back tears reminiscing about losing his friend; another veteran tells about nightmares later in life. ${ }^{71}$ The series reminds the viewers of the price of freedom, of the brutality of war. One of the veterans states: "I've seen death. I've seen my friends, my men, being killed. And this is ... it doesn't take too many days of that and you change dramatically." 72 The loss of soldiers' lives appears heartbreaking due to the friendships between the soldiers which is the main focus of the series.

Another negative aspect of the war is the random deaths of young soldiers. From officers accidentally shot by their own men, to a soldier who dies because the gun in his pocket accidentally goes off, to the soldier who dies in a car crash after the end of the war-this is to remind the viewers that not all fallen soldiers died heroic deaths. In episode 7, a soldier is crawling towards a foxhole where two other soldiers are hiding during a German attack. When he is a few yards from the foxhole, it is hit by a grenade and the two soldiers die instantly. He climbs into the next one where another grenade hits - but it does not explode. Dying in action is not necessarily due to heroism or cowardice; mostly it is simply being at the wrong place, at the wrong time. Furthermore, the soldiers of Easy Company have no fondness for battle or violence. A replacement soldier asks when he is going to "see some action," only to be met with anger from one of the more experienced soldiers. ${ }^{73}$ The series also mocks the visual "evidence" that is taped to heighten moral at the home front. The soldiers are smiling and joking at the camera, not mentioning the cold weather, the lack of supplies, or the frequent German attacks. ${ }^{74}$

The criticism of war and the display of its brutality and randomness are mostly used to encourage gratitude in America for the sacrifices made by the American soldiers. It is important to honor the heroic actions of the soldiers. Thus, it fits into the larger tendency in the revival of WWII: it is

70 "Carentan" (Episode 3), directed by Mikael Salomon, Band of Brothers.

71 "The Breaking Point" (Episode 7), directed by David Frankel, Band of Brothers.

72 "The Breaking Point"

73 "Why We Fight" (Episode 9), directed by David Frankel, Band of Brothers.

74 "The Breaking Point" (Episode 7), Band of Brothers. 
important that the younger generations remember the heroic actions and sacrifices made by earlier generations. It is also on the issue of the soldiers' experiences that the Vietnam films have made a significant contribution to WWII movies. The Vietnam War ruined the myth that war itself was a matter of pride and honor-the WWII myths of the 1990s acknowledged this shift; yet they reinstated the notion of the soldiers as fundamentally good. This places Band of Brothers within Stahl's notion that modern war films are anti war, but pro soldiers.

\section{The Greatest Generation}

Above all, Band of Brothers is the story of "the Greatest Generation." As the title indicates, the main narrative focus is the comradeship between the soldiers, not the overall political context of the war. The tagline of the series was: "The world depended on them. And they depended on each other." The series maintains its focus on "the Greatest Generation" by promoting a large ensemble. Major Winters is the main character in the first 5 episodes; thereafter other characters' stories are told. The focus is narrowed by the personal identification at the beginning of each episode. In the next episodes other protagonists are used, e.g. the medic Eugene Roe. The purpose of his story is to illustrate that it is not necessarily the participation in combat, but just witnessing it, that can traumatize a soldier. The use of eyewitness accounts from veterans shows the series' focus on the average American soldier. The purpose of the series is to tell the story of average Americans who made extraordinary heroic actions when it was required of them. It is in the portrayal of the soldiers that the myths of WWII most clearly manifest themselves in the series.

Another myth confirmed by the series is that of the WWII melting pot and the unit as a symbol of nationality. Throughout the series, very little information is presented about each character's background, although there are a few references to some characters being Italian-Americans, Jewish, etc. The WWII genre's dislike of officers, as argued by Slotkin, also appears in Band of Brothers. Especially upper-class officers are disliked. One of the soldiers, Private Webster, is mocked for his Harvard education; a bad officer is referred to as "another Yale asshole". ${ }^{75}$ There are some refernces to the 
religious backgrounds of the soldiers, e.g. there is some playful discussion about Winters being a Quaker. However, religious and ethnic differences are accepted as long as soldiers fight heroically for their fellow soldiers. Replacement soldiers have to prove themselves in combat before they are accepted into the group. Thus, the military becomes the embodiment of the American ideal of a society based on meritocracy. In combat, it is not religion, ethnicity, or social standing that determines a soldier's courage and ability to fight. Not only are there few references to the soldiers' social background, but the mention of home, families, hometowns, etc., is mostly saved for the final episodes. In the final minutes of the series, the audience is provided with an overview of the backgrounds and post-war lives of the soldiers. One is the prosecutor who had Robert Kennedy's assassin convicted; another is a cab driver; a third is a wealthy heir. Despite their differences, they are tied together by their experience in the war. Just to make sure the viewers get the point, the information of their post-war lives are presented while they play baseball-the all-American team sport.

The main protagonist is Major Richard Winters who is the embodiment of "the Greatest Generation." Completely unselfish and untouchable in combat, he is the perfect leader because of his lack of ambition on his own behalf. Other leaders, such as Captain Sobel, Easy Company's first leader, and Norman Dike, who suffers a mental breakdown during combat, are both more concerned with the prestige of their rank than the well-being of their men. Apparently, Dike was given command of Easy due to his wealth and connections - a powerful contrast to Winters who earns not only the command but also the respect of the men through courageous actions. Dike also violates the most sacred of rules-he leaves his men in the mid of an attack. As mentioned previously, the main theme of the story is the loyalty between the soldiers; Dike violated this and must pay. ${ }^{76}$

A noticeable omission in the series is the lack of wrongdoing by the men of Easy Company. Sobel and Dike might be cowards and incompetent, but they are not evil. There are no random killings of civilians or innocents (although there are rumors that one of the officers killed 30 German POWs, but the mystery remains unsolved ${ }^{77}$ ), no rapes of civilian women, etc. The brutal, random killings are left to the Europeans, whether it is the Holocaust, Soviet soldiers killing German POWs, or the civilian population in

77 "Day of Days" (Episode 2), directed by Richard Loncraine, Band of Brothers. 
a Dutch village harassing the girlfriends of German soldiers. The overall message is that the men of Easy Company were all good men; thereby implicitly revealing the notion that Americans were thought to be more moral than the Europeans.

\section{The enemy}

Since the focus in Band of Brothers is mainly on the friendship between the soldiers, a large-scale, political focus is mostly missing from the series. Japan-the initial reason for American intervention in the war-is not mentioned until the very last episode. Hitler is mentioned a few times throughout the series because Easy Company invades his home in Berchtesgaden, but the series offers very little political context for the viewer. Instead, the historical context is presented at the end of every episode. The story is told from the point of view of the soldiers, and their focus was on day-to-day survival, not on the larger political reasons for war. When the U.S. intervened in Europe, the outcome of the war had in reality already been determined, so it was a matter of survival rather than victory. ${ }^{78}$ However, there are very few references to other nations. In one episode, Easy Company goes on a rescue mission to save a group of British soldiers, ${ }^{79}$ and they witness Soviet soldiers executing German POWs, ${ }^{80}$ but other allied soldiers are absent from the series. Very little information is given about the sacrifices made by other nations in the war.

German soldiers often appear, but mostly as faceless enemies. In the last episode of the series, Easy Company supervises the surrender of a German company, and Major Winters stresses the importance of treating them with respect. ${ }^{81}$ A German officer speaks to his men, about how they deserve "long and happy lives in peace." One of the U.S. soldiers translates for the other soldiers - the message is that the values of the German soldiers are the same as the Americans-loyalty, comradeship, etc. It is war that forces these young men to become enemies. Thus, the criticism is not directed at the Germans, but at war itself. Generally, the series' portrayal of Europe is very positive. Most civilians, especially in The Netherlands and even in 
Germany, welcome the U.S. soldiers. Europe is portrayed as being grateful for the presence of the American military; an indication of America's view that Europe owes the U.S. for its peace. Thus, a crucial component of WWII mythology is the brutality of the Nazis rather than the Germans. The close political relationship between the U.S. and Germany in the post-war period would make a negative portrayal of all Germans highly unlikely, thus reflecting contemporary concerns.

\section{The Holocaust and moral war}

Episode 9 of the series is titled "Why We Fight." ${ }^{2}$ Whereas other episodes depict the battles of the company, this episode provides the viewers with the moral justification for WWII. Private Webster is becoming increasingly frustrated by the pointlessness of the war and asks a German soldier: "Why are we here?" Later in the episode, Easy Company discovers a concentration camp and is horrified by the sight. None of the soldiers state it explicitly, but this is clearly the answer to Webster's question. In Stephen E. Ambrose's book, on which the series is based, the incident fills less than a page. ${ }^{83}$ In the series, almost an entire episode is dedicated to it. With the discovery of the Holocaust, the view of the war changes. It is not just a matter of fighting over territory; it has become a moral mission to save Europe from its own fate. Thus, it both presents the war in a moral light and, once again, presents the Americans as more moral than the Europeans. The soldiers are particularly shocked that the German civilians of a nearby town did not try to prevent the killings. Easy Company is depicted as having no knowledge about the existence of these camps or the reason for them. In fact, they are shocked when learning that anti-Semitism was the motivation for the camps. Easy Company here serves as symbol of America; they had no knowledge of the Holocaust so the rest of America could not have known either. This way, America is completely vindicated of any guilt in the Holocaust. The shift in the sense of mission is clearly stated in two scenes from this episode. In the first scene, Captain Nixon is breaking into German houses looking for a particular brand of whisky. Eventually, he

82 Why We Fight was also the title of a famous series of documentaries (made for propaganda purposes) directed by Frank Capra during the war.

83 Ambrose, Stephen E., Band of Brothers: E Company, 506 ${ }^{\text {th }}$ Regiment, $101^{\text {st }}$ Airborne: From Normandy to Hitler's Eagle's Nest (New York: Simon and Schulster, 2001), pp. 262-263. 
breaks into a house where he finds a photograph of a German officer on the mantelpiece. Nixon breaks the frame, only then to discover a woman's presence-the officer's wife. The woman looks at Nixon with pride and contempt. Nixon is ashamed of his own behavior and silently leaves the house in shame. Later, German civilians are forced to dig up the victims from the concentration camp. At the camp, Nixon meets the woman from the house-she is disgusted by what she is being forced to do. However, after facing Nixon's accusing stare, she bows her head in shame (similar to Nixon in the former scene) and returns to her work. America's role as the intruder is hereby justified.

The use of the Holocaust in this series, and in many other WWII films, can be seen as a justification for America's later intervention in many countries. After the end of the Cold War and especially Vietnam, the very project of war seems pointless and unnecessary. The soldiers' sense of pointlessness could reflect the feelings some might have about contemporary wars. The series offers redemption - the purpose of the war might not be obvious, but eventually history will vindicate America's actions. It is in its comment on the Holocaust and the moral justification for war that Band of Brothers most obviously relates to contemporary debates.

\section{Conclusion}

Band of Brothers marks the culmination of the WWII revival, and in some ways, also its end. WWII is still a subject that receives a lot of attention, but after 2001 the American nation had a new enemy, a new war to fight. The series incorporated several myths about WWII. It questioned the myth of war as positive since it depicted the devastating experiences of American soldiers. The series especially objected to the notion that soldiers were left mentally and emotionally unaffected by the war. Yet, WWII is portrayed as fundamentally different from other wars, and the Holocaust proved the necessity of the war. Thus, the myths of war in the WWII revival found a synthesis between the anti-war sentiments of the Vietnam era and the protection of WWII as the creation myth of modern America. The series' main criticism is of the very nature of war itself. It most clearly confirms the myth of "the Greatest Generation" by its overwhelmingly positive portrayal of Easy Company and the special bond the soldiers shared. Despite the brutality of war, it is not pointless. In terms of criticism of war in general, the focus on the Holocaust, and the friendship of the soldiers, Band 
of Brothers is a typical representative for the revival of the WWII film. Aesthetically and thematically, it has much in common with Saving Private Ryan; however, the series is considerably less violent, choosing to focus on the friendships between the soldiers rather than on combat scenes. By the use of real-life characters and the focus on friendship, the series manages to create an emotional link for a contemporary audience to the war and thus imposing values of just war on the viewers. Also, Band of Brothers achieved an extraordinary level of authenticity, thus making it the "official" version of the American experience in Europe during WWII and therefore a significant contribution to the modern mythology of WWII.

The true power of the myths of WWII reveals itself in times of crisis. The notion of just and necessary war that has emerged from the WWII mythology has continued to affect America's foreign policy. Thus, the War on Terror reflects the belief that "evil" exists, and that it is a genuine threat to American society. According to Edward W. Wood Jr., the concept of just and necessary war provided by WWII is the background for American intervention in Iraq; namely that America has the right to use violence against a nation it considers "evil." 84 However, the war in Iraq is also an example of how the Vietnam War still affects America's view of war. The American intervention was based on the notion that Saddam Hussein was "evil," and thus America had the right to intervene. The joy of the Iraqi people as Hussein was removed from power once again showed the American people (as in Europe in the 1940s) that they were popular and considered liberators by the Iraqi people. However, as soon as the public sentiment in Iraq turned against America and the war turned out to be longer and far more deadly than expected, the Vietnam trauma reappeared. Americans were afraid that they were going to be drawn into a long war without victory in sight, and the fear of a new Vietnam appeared. Thus, America has come to idealize war due to WWII, but the revival of WWII has been unable to fully heal the wounds of Vietnam.

However, it will probably not be the last time America returns to the safe harbor of the WWII myth. It continues to be idealized as the standard all other wars are measured against. As "the Greatest Generation" will all soon be gone, the last chance of reacting against the myths disappears. Band of Brothers presented WWII from a 1990s perspective, reflecting the issues of 
the WWII revival and providing the values necessary in the contemporary cultural agenda. WWII has become the war that helps America win its other wars - cultural wars even more than the military ones. 